\title{
MTHFR gene polymorphisms as risk factors for colorectal cancer among Egyptian patients.
}

\author{
Rizk A. El-baz ${ }^{1}$; Camelia A. Abdel Malak²; Saleh Ibrahim El-Awady ${ }^{3}$ \\ Amira Kazamel ${ }^{4}$, Fatma A .El tarpely ${ }^{2}$. \\ ${ }^{1}$ Genetics Unit, Children Hospital, Mansoura University, Egypt \\ ${ }^{2}$ Biochemistry Department, Damitta Faculty Of Science, Mansoura University. \\ ${ }^{3}$ Cancer Institute, Mansoura University, Egypt. \\ ${ }^{4}$ Zology, Faculty of Science, Mansoura University, Egypt
}

\begin{abstract}
Objective: Polymorphisms in methylenetetrahydrofolate reductase (MTHFR), such as MTHFR C677T and A1298C, are associated with several cancers. This study aimed to evaluate the effects of MTHFR polymorphisms on colorectal cancer risk in a population from damitta Egypt. Methods. This hospital-based case-control study was conducted during 2008-2010; 64 colon cancer cases and 90 controls were enrolled. Information was collected and blood samples were obtained for assay of MTHFR C677T and A1298C polymorphisms by polymerase chain reaction-single strand conformation polymorphism (PCR-SSCP) and PCR-restriction fragment length polymorphism (PCR-RFLP) techniques. Associations between variables of interest and colorectal cancer were assessed using conditional logistic regression. Results: Increased risk of colorectal cancer was associated with the MTHFR C677 TT genotype of C677T polymorphism $(\mathrm{OR}(\operatorname{adj})=24.0 ; 95 \% \mathrm{CI}: 1.34-429.1 ; \mathrm{P}$ value for interaction $=0.001)$. The 1298AC genotype and $\mathrm{C}$ allele was associated with a statistically significant lower risk among subjects (OR, 3.85; 95\% CI, 1.78-8.33; $\mathrm{P}$ value for interaction=.0005 and OR,1.88;95\% CI, 1.16-3.059 P value for interaction=0.01), respectively. MTHFR 1298 AA genotype and A allele was found to be associated with a significantly decreased risk for colorectal cancer $(\mathrm{OR}=0.25,95 \% \mathrm{CI} 0.11$ 0.52 ; $\mathrm{P}$ value for interaction $=0.0005$ and $\mathrm{OR}=0.52,95 \% \mathrm{CI} 0.32-0.85 \mathrm{P}$ value for interaction $=$ 0.01 and ), respectively. There was no clear relation between colorectal adenomas and those with the 1298 CC genotype. The combined CC , AA [corrected] genotypes and the CT+AA [corrected] genotypes and the TT+ AC were associated with a statistically significant lower risk for developing colorectal cancer $(\mathrm{P}$ value for interaction $=0.03,0.02,0.001)$, respectively .
\end{abstract}

CONCLUSIONS: The findings suggest an interaction between the MTHFR genotype and colorectal adenomas among Egyptian patients.

Abbreviations: T2DM: Colorectal cancer- MTHFR: methylenetetrahydrofolate reductase SNP: single nucleotide polymorphism- SSP-PCR: sequence specific primer- polymerase chain reaction.

Key words: MTHFR gene - Colorectal cancer.

\section{Introduction}

Colorectal cancer is one of the most common cancers in the world, accounting for nearly $10 \%$ of new cases of all cancers (Parkin, et al ., 2005). The incidence of colorectal cancer varies substantially worldwide, with high rates in Western countries and low rates in African and Asian countries in general (Stewart et al .
2006). Methylenetetrahydrofolate reductase (MTHFR) is an enzyme which catalyzes the reduction of $5,10-$ methylenetetrahydrofolate to 5methyltetrahydrofolate (MTHF), the predominant circulatory form of folate and carbon donor for the re-methylation of homocysteine to methionine (Donnelly, 2001 and Fowler, 2005). Several polymorphisms have been described that result in amino acid changes, which could 
lead to altered MTHFR enzymatic activity (Donnelly, 2001 \& Toffoli and De Mattia, 2008).The best-characterized being the C677T, a valine-to-alanine substitution at amino acid 226, which was reportedly linked with moderate hyperhomocysteinemia when folate levels are low in homozygotes (677T/T) compared with heterozygotes or noncarriers (Friedman et al., 1999\& Almawi et al., 2004).The A1298C missense mutation is an additional MTHFR gene polymorphism located in the enzyme regulatory domain (van der Put et al., 1998 \& Friedman et al., 1999 ), but unlike the C677T found within the enzyme catalytic domain, it does not result in either a thermolabile protein or with increased homocysteine (Hanson et al., 2001 \& Friso et al., 2002). It is considered that alteration of DNA methylation is associated with carcinogenesis and is not just an accompanying phenomenon (Choi \& Mason , 2002). Two functional, common polymorphisms (C677T and A1298C) are known in the MTHFR gene. In this review, we evaluate the consistency of reported associations of the MTHFR polymorphisms with colorectal cancer .

\section{Aim of the work:}

The objective of the present work is to Detection the relation of MTHFR C677T and A1298C polymorphisms to colorectal cancer.

\section{Subject and methods}

\section{Subjects:}

The present study was conducted on a total of 64 adult patients aged between $23-73$ years with a mean $47.73 \pm 12.72$, the number of males is 38 aged between $23-$ 73 , and the number of females is 26 aged between 32-73. Patients selected from the Cancer Institute, Mansoura University, Egypt in the period between January and September 2009. In addition, 90 normal healthy control randomly selected from blood donors. The samples were taken from the blood of all patients and controls after their routine check up by their own consent.The work took the approval of ethical committee of National Cancer Institute.

\section{Method:}

\section{DNA extraction and purification}

After obtaining informed consent from all cases and controls, venous blood samples (3 ml) were collected on EDTA (ethylenediamine tetra acetate) containing tubes, DNA was extracted promptly using DNA extraction and purification kit (Gentra Systems, USA) according to manufacturer's instructions and then stored at $-20{ }^{\circ} \mathrm{C}$ till use.

\section{PCR amplification}

MTHFR C677T genotype analysis was performed by PCR-RFLP analysis.

The primer sequences for C677T were: Forward: (5'- TGA AGG AGA AGG TGT CTG CGG GA- 3') and Reverse: (5'-AGG ACG GTG CGG TGA GAG TG- 3' ) (Gibeo BRL).For PCR the following procedure was used: preliminary denaturation at $95^{\circ} \mathrm{C}$ for $3 \mathrm{~min}, 5$ cycles: denaturation at $94^{\circ} \mathrm{C}$ for $1 \mathrm{~min}$, annealing at $64^{\circ} \mathrm{C}$ for $1 \mathrm{~min}$, synthesis at $72^{\circ} \mathrm{C}$ for 30 sec, next 30 cycles were run: denaturation at $94^{\circ} \mathrm{C}$ for $45 \mathrm{sec}$, annealing at $62^{\circ} \mathrm{C}$ for $45 \mathrm{sec}$, synthesis at $72^{\circ} \mathrm{C}$ for $25 \mathrm{sec}$ and final synthesis at $72^{\circ} \mathrm{C}$ for $7 \mathrm{~min}$. Digestion was performed by restrictase HinfI (Fermentas, USA) at $37^{\circ} \mathrm{C}$ for $4 \mathrm{~h}$. For evaluation of MTHFR A1298C polymorphism, the following primers were used: Forward: (5'- CTT TGG GGA GGT GAA GGA CTA CTA C- 3') and Reverse: (5'- CAC TTT GTG AGC ATT CCG GTT TG- 3') (Gibeo BRL). The PCR procedure was composed of preliminary denaturation at $95^{\circ} \mathrm{C}$ for $2 \mathrm{~min}, 5$ cycles: denaturation at $95^{\circ} \mathrm{C}$ for $1 \mathrm{~min}$, annealing at $55^{\circ} \mathrm{C}$ for 2 min, synthesis at $72^{\circ} \mathrm{C}$ for $2 \mathrm{~min}$, next 32 cycles were run: denaturation at $95^{\circ} \mathrm{C}$ for $75 \mathrm{sec}$, annealing at $55^{\circ} \mathrm{C}$ for $75 \mathrm{sec}$, synthesis at $72^{\circ} \mathrm{C}$ for $90 \mathrm{sec}$ and final synthesis at $72^{\circ} \mathrm{C}$ for $6 \mathrm{~min}$. Restrictase 
MboII was used for digestion at $37^{\circ} \mathrm{C}$ for 7h. (Siemianowicz et al., 2003).

\section{Detection of amplified and digested products}

The entire reaction volume plus $5 \mu 1$ of bromophenol blue track dye were loaded into 2\% agarose gel (Boehringer Mannheim) containing ethidium bromide. Gels were electrophoresed for 30 minutes at $100 \mathrm{~V}$, photographed under UV light (320 $\mathrm{nm}$ ) and then scored for the presence or absence of an allele specific band.

\section{Statistical analysis:}

Data were processed and analyzed using the Statistical Package of Social Science (SPSS, version 10.0). The frequency of studied allelic polymorphisms were compared between groups by using Fisher's exact test (modified Chi square test) and Odds ratio. A value of $\mathrm{P}<0.05$ was considered to be significant.

\section{Results}

Comparing studied cases of Colorectal cancer to that of Healthy controls regarding the distribution of MTHFR C677T and A1298C genotypes and alleles(table 1, fig.1,2) showed that cases of colorectal cancer had a significantly higher frequency of the homozygous mutated TT genotype of C677T polymorphism $(10.9 \%$ vs. $0 \%$, $\mathrm{p}=0.001)$. On the other hand they had a significantly lower frequency of heterozygous mutated $\mathrm{AC}$ genotype and $\mathrm{C}$ allele of A1298C polymorphism compared to controls $(82.8 \%$ vs. $55.6 \%, \mathrm{p}=0.0005$ and $41.4 \%$ vs. $27.8 \%, p=0.01$, respectively), while they had a significantly higher frequency of wild AA genotype and A allele of A1298C polymorphism compared to controls $(17.2 \%$ vs. $44.4 \%, \mathrm{p}=0.0005$ and $58.6 \%$ vs. $72.2 \%, \mathrm{p}=0.01$, respectively).

Comparing all studied cases of colorectal cancer to that of healthy controls regarding their combined genotypes of C677T and A1298C polymorphisms of MTHFR gene ( table 2), it is noted that cases had a significantly lower frequency of combined (CC and AA) genotypes and (CT and AA) genotypes compared to controls $(6.25 \%$ vs. $18.9 \%, \mathrm{p}=0.03 \& 11.0 \%$ vs. $25.6 \%, \mathrm{p}=$ $0.02)$. While they had a significantly higher frequency of combined (TT and AC) genotypes 
Table (1): Comparison between all cases colorectal cancer and healthy controls regarding their allele frequency and genotype distribution of C677T and A1298C polymorphisms of MTHFR gene.

\begin{tabular}{|l|l|l|l|l|}
\hline & cases & Healthy controls & $(\mathbf{P})$ & OR(95\% CI) \\
& $\mathbf{n}(\%)$ & $\mathbf{n}(\%)$ & & \\
\hline C677T & & & & \\
\hline Genotypes & $64(100.0)$ & $90(100.0)$ & & \\
\hline CC & $26(40.6)$ & $40(44.4)$ & 0.7 & $0.87(0.4-1.6)$ \\
\hline CT & $31(48.4)$ & $50(55.6)$ & 0.4 & $0.7(0.38-1.3)$ \\
\hline TT & $7(10.9)$ & $0(0.0)$ & $\mathbf{0 . 0 0 1 * *}$ & $24.0(1.34-429.1)$ \\
\hline Alleles & & & & $0.7(0.43-1.17)$ \\
\hline C & $83(64.9)$ & $130(16.7)$ & 0.2 & $1.3(0.85-2.27)$ \\
\hline T & $45(35.1)$ & $50(27.8)$ & 0.2 & \\
\hline A1298C & & & & \\
\hline Genotypes & & & & $0.25(0.11-0.52)$ \\
\hline AA & $11(17.2)$ & $40(44.4)$ & $\mathbf{0 . 0 0 0 5 * *}$ & $3.85(1.78-8.33)$ \\
\hline AC & $53(82.8)$ & $50(55.6)$ & $\mathbf{0 . 0 0 0 5 * *}$ & 0 \\
\hline CC & $0(0.0)$ & $0(0.0)$ & 0 & $0.52(0.32-0.85)$ \\
\hline Alleles & & & $\mathbf{0 . 0 1 *}$ & $1.88(1.16-3.05)$ \\
\hline A & $75(58.6)$ & $130(72.2)$ & $50(27.8)$ & \\
\hline C & $53(41.4)$ & & & \\
\hline
\end{tabular}

$n=$ number of cases, $(\%)=$ percentage of cases, $O R(95 \%$ CI $)=$ Odds ratio \& $95 \%$ confidence interval Significance using Fisher's Exact test: 
Table (2): Comparison between all cases of colorectal cancer and healthy controls regarding the frequency of their different combined genotypes of C677T and $\mathrm{A1298C}$ polymorphisms of MTHFR gene.

\begin{tabular}{|l|l|l|l|}
\hline $\begin{array}{r}\text { Combined } \\
\text { genotyp } \\
\text { es }\end{array}$ & $\begin{array}{l}\text { cases }(\%) \\
\text { Total }\end{array}$ & $\begin{array}{l}\text { Healthy controls } \\
n(\%)\end{array}$ & P \\
\hline CC and AA & \multicolumn{1}{|c|}{$4(6.25)$} & \multicolumn{1}{|c|}{$17(18.9)$} & $0.03 *$ \\
\hline CC and AC & $22(34.4)$ & $23(25.6)$ & 0.28 \\
\hline CT and AA & $7(11.0)$ & $23(25.6)$ & $0.02^{*}$ \\
\hline CT and AC & $24(37.5)$ & $27(30.0)$ & 0.38 \\
\hline TT and AC & $7(11.0)$ & $0(0.0)$ & $0.001^{* *}$ \\
\hline
\end{tabular}

$n=$ number of subjects, $(\%)=$ percentage of subjects, $* p=<0.05$ (significant) $* * p=<0.001$ (extremely significant)

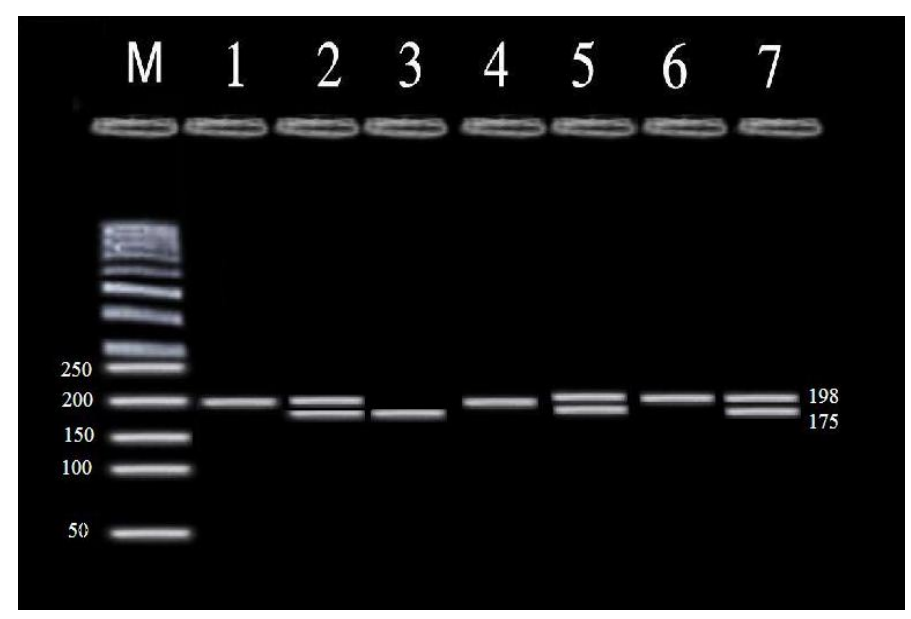

Fig (1) Digestion of PCR product of C677T polymorphism of MTHFR gene using HinfI enzyme. which digests the 198- bp fragment into 175- and 23- bp frgments; the small 23- bp fragment has run off the gel. Lane M: DNA size marker (50 bp), lane 1,4and 6 (wild type CC is found which appears at $198 \mathrm{bp}$ ), lane 2,5and 7 (heterozygous mutated genotype CT which has 198, 175, 23 bp fragments), lane 3 ( homozygous mutated genotype TT which has 175, 23 bp fragments); the small 23- bp fragment has run off the gel. 


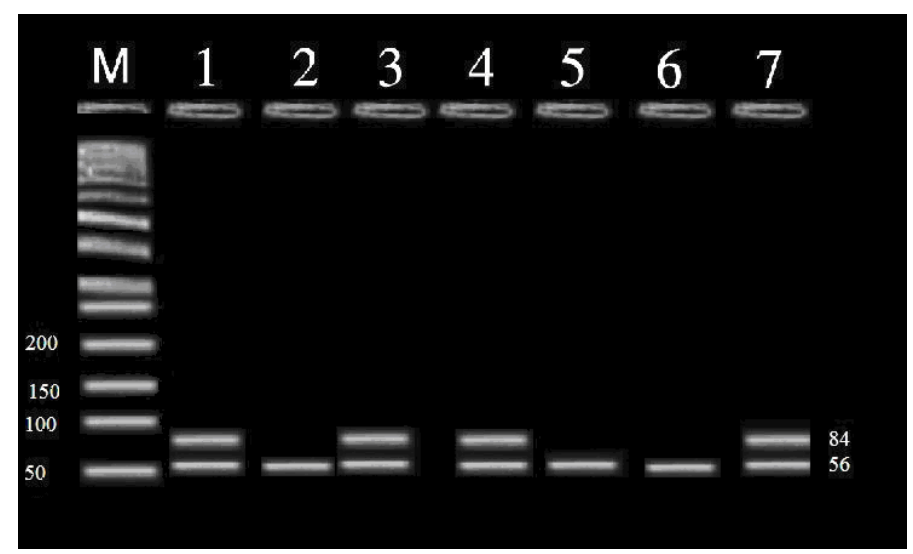

Fig (2) : Digestion of PCR product of A1298C polymorphism of MTHFR gene using MobII enzyme which digests the $163 \mathrm{bp}$ fragment the wild-type AA into five fragments 56, 31, 30, 28 and 18 ; the small 18, 28, 30, $31 \mathrm{bp}$ fragments have run off the gel. Lane M : DNA size marker (50 bp), Lane 2,5, and 6 (wild type AA), lane 1,3,4 and 7(heterozygous mutated type AC ).

\section{Discussion}

Colorectal cancer is the third most common cancer and the fourth most frequent cause of cancer death world-wide, accounting for $9.4 \%$ and $7.9 \%$ of all cancer cases and deaths, respectively. In more developed countries, colorectal cancer is the second most frequent cancer type and cause of cancer death, accounting for $13.3 \%$ and $11.7 \%$ of the cases, respectively .There is up to a 20-fold difference in incidence between the high rates experienced in the economically developed countries of Australia, Europe, Japan and North America versus those of central Africa, the Indian sub-continent and southern Asia (Ferlay et al., 2004).

Methylenetetrahydrofolate reductase (MTHFR) is a key enzyme regulating folate metabolism. It irreversibly converts 5,10methylenetetrahydrofolate to 5methyltetrahydrofolate, which is the major form of folate in blood (Sharp \& Little, 2004). The substrate of MTHFR, 5,10methylenetetrahydrofolate, is required for conversion of deoxyuridylate to thymidylate. Depletion of 5,10methylenetetrahydrofolate results in uracil misincorporation into DNA, and removal of this abnormal base may lead to single and double strand breaks (Blount et al ., 1997; Duthie,1999). Furthermore, insufficient thymidylate can increase DNA misrepair, resulting in overall DNA damage in the cell (Duthie et al ., 2000). On the other hand, 5-methyltetrahydrofolate provides the methyl group for methylation of homocysteine to methionine. Imbalanced DNA methylation, i.e., global genomic hypomethylation and methylation of usually unmethylated $\mathrm{C}$ - phosphate- $\mathrm{G}$ site $(\mathrm{CpG})$ sites, has been implicated in colorectal carcinogenesis (Toyota et al ., 1999 and van Rijnsoever et al ., 2002 ).

DNA methylation is a crucial epigenetic determinant in gene expression, maintenance of DNA integrity and stability, chromatin modifications and development of mutations did find a significant excess of 677TT individuals among patients with Colorectal carcinomas (CRC). Indeed, induction of DNA damage and disruption of its DNA integrity, impaired DNA repair and hypermutability are generally considered to be the primary mechanisms by which folate deficiency enhances colorectal carcinogenesis (Duthie, 1999 ; Choi \& Mason, 2002).

The current study aims mainly to investigate the association of C677T and A1298C polymorphisms of Methylenetetrahydrofolate reductase (MTHFR) gene and their combined effect with colorectal cancer among Egyptian cases of colorectal cancer. 
This data showed that homozygous mutated TT genotype of C677T polymorphism had a significantly higher frequency among cases of colorectal cancer compared to controls At position 677, TT genotype frequency was $10.9 \%$ with an odds ratio \{OR \} of 24.0 [95\% confidence interval $\{\mathrm{CI}\} 1.34-429.1, \mathrm{P}=0.001]$. Thus TT genotype may be considered as genetic risk factor for colorectal cancer. This results are in agreement with the following results : El Awady et al.(2009), Levine et al. (2010), Cui et al . (2010). El Awady et al.(2009) study among 35 cases of Colorectal carcinomas (CRC) and 68 healthy controls suggested that at least one $\mathrm{C}$ to $\mathrm{T}$ polymorphism at $677 \mathrm{MTHFR}$ gene is required to significantly increase the risk for CRC development. Further large scale studies are required to confirm the present findings. Frequencies of heterozygous and homoyzgous polymorphisms of MTHFR at positions 677 in carcinoma tissues were always the highest. At position 677, TT and CT genotype frequencies were $17 \%$ and $66 \%$ with an odds ratio $\{\mathrm{OR}\}$ of 11 [95\% confidence interval $\{\mathrm{CI}\}$ 2.39-50.59] and OR 8.34 [95\%CI 2.97-23.92], respectively, in carcinoma tissues. While in the germ line of patients the genotype frequencies of $677 \mathrm{TT}$ and CT were $6 \%$ and $54 \%$ with OR 1.57 [95\%CI $0.26-9.51]$ and 2.99 [95\%CI 1.25-7.12], respectively, compared to controls (6\% and 29\%, respectively) in Egypt. Levine et al. (2010) study in, Los Angeles, USA. Suggested that the MTHFR C677T TT genotype is associated with a $15 \%$ to $18 \%$ reduction in colorectal cancer risk, but it is not clear if other variants of the gene are associated with colorectal cancer risk. The 677 TT genotype was associated with a decreased risk of microsatellite-stable/microsatellite-low tumors (OR, 0.69; 95\% CI, 0.49-0.97) and an increased risk of microsatellite-high tumors (OR, 2.22; 95\% CI, 0.91-5.43; $\mathrm{P}($ interaction $)=0.01)$, as well as an increased risk of proximal cancers and a decreased risk of distal and rectal cancers $(\mathrm{P}($ interaction $)=0.02)$. No other single nucleotide polymorphism was associated with risk overall or within subgroups.
Cui et al . (2010) study was designed to investigate an association between the methylenetetrahydrofolate reductase (MTHFR) C677T polymorphism and the risk of gastric and colorectal cancer in the Korean population . The MTHFR 677TT genotype showed a weak opposite association with colorectal cancer compared to the homozygous CC genotype [adjusted age and sex odds ratio $(\mathrm{OR})=$ $0.792,95 \%$ confidence interval $(\mathrm{CI})=$ $0.638-0.984, \mathrm{P}=0.035]$.Subjects with the MTHFR 677CT showed a significantly reduced risk of gastric cancer compared those with the 677CC genotype (age- and sex-adjusted OR $=0.810$; 95\% CI $=0.696$ $0.942, \mathrm{P}=0.006$ ). It is observed no significant interactions between the MTHFR C677T polymorphism and smoking or drinking in the risk of colorectal cancer. The $\mathrm{T}$ allele was found to provide a weak protective association with gastric cancer and colorectal cancer .

In contrast, These results are in disagreement with the present results, $L e$ Marchand et al.,(2005), Kono \& Chen , ( 2005) , Mokarram et al (2008), Le Marchand et al.(2005) founded that an inverse association between colorectal cancer risk and the TT genotype, with odds ratios (OR; and 95\% confidence intervals) for the CC, CT, and TT genotypes of 1.00 , 1.01 (0.84-1.21), and 0.77 (0.58-1.03), respectively. This association was similar in both sexes in Hawaii, USA. Such an association had been seen in some previous studies (Curtin et al ., 2004, Ulrich et al ., 1999). Kono \& Chen,(2005) founded that a Decreased risk of colorectal cancer associated with the 677TT genotype has fairly consistently been observed in Japan . Mokarram et al.(2008) showed an increased risk of tumor methylation was associated with the CT genotype $(\mathrm{OR}=2.5$; 95\% CI, 1.1-5.6) in comparison to controls with the CC genotype in Iran .

Regarding genotypes and alleles of A1298C polymorphism, this data showed that a significantly lower frequency of heterozygous mutated $\mathrm{AC}$ genotype and $\mathrm{C}$ allele of A1298C polymorphism compared to controls $(82.8 \%$ vs. $55.6 \%, \mathrm{p}=0.0005$ and $41.4 \%$ vs. $27.8 \%, \mathrm{p}=0.1$, respectively), 
while they had a significantly higher frequency of wild AA genotype and A allele of A1298C polymorphism compared to controls $(17.2 \%$ vs. $44.4 \%, \mathrm{p}=0.0005$ and $58.6 \%$ vs. $72.2 \%, \mathrm{p}=0.01$, respectively). There is no significant frequency in homogenous mutated CC of 1298 genotype. Our results are in agreement with results of El Awady et al.(2009), Chandy et al., (2010 ). El Awady et al.(2009) founded that Frequencies of MTHFR677T and 1298C alleles were significantly higher among cases of CRC tumor tissues (50\% and 56\%, respectively) than germ line alleles in CRC patients (33\% and $41 \%$, respectively) and healthy controls $(21 \%$ and $35 \%$, respectively) in Egypt. Chandy et al. (2010) study was under taken to analyse the association of the MTHFR gene polymorphisms $677 \mathrm{C}-->\mathrm{T}$ and $1298 \mathrm{A-->C}$ and risk of colorectal cancer (CRC) in India. The OR for $677 \mathrm{CT}$ was $1.18(95 \%$ CI $0.59-2.32, \mathrm{P}=0.642$ ), $\mathrm{OR}$ for $1298 \mathrm{AC}$ was $1.68(95 \% \mathrm{CI} 0.92-3.08, \mathrm{P}=0.092)$ and OR for $1298 \mathrm{CC}$ was 0.45 (95\% CI 0.18 $1.12, \mathrm{P}=0.081)$. The $\mathrm{OR}$ for the combined heterozygous state (677 CT and $1298 \mathrm{AC}$ ) was 1.18 (95\% CI 0.52-2.64, $\mathrm{P}=0.697$ ).

Regarding genotypes and alleles of A1298C polymorphism, we found our cases of colorectal cancer are in disagreement with the results of, Curtin et al.(2004) who founded that the 677CC/1298CC (wild-type/variant) genotype was associated with a statistically significant lower risk among women (OR, 0.6 ; 95\% CI, 0.4-0.9) but not men. When the polymorphisms were considered individually, for A1298C a significant risk reduction associated with the homozygous variant CC genotype was seen among women only (OR, 0.6; 95\% CI, 0.5-0.9), this study supports recent findings that the MTHFR A1298C polymorphism may be a predictor of colon cancer risk and have functional relevance. The possible interaction with hormone-replacement therapy warrants additional investigation and these results are in agreement with our result for AA and AC genotypes .

Zhang et al. (2007) supported the role of the A1298C polymorphism in MTHFR as prognostic marker in female patients with metastatic colon cancer. Further studies are needed to confirm these findings. The A1298C polymorphism showed statistically significant differences in overall survival (OS) in female, but not male, patients with metastatic colon cancer (log-rank test, $\mathrm{P}=$ .038). Among females, Overall survival (OS) was greater for patients with the A/A genotype ( $\mathrm{n}=67$; median OS, 18.4 months) compared with patients with the A/C genotype $(\mathrm{n}=50$; median Overall survival (OS), 13.9 months) or $\mathrm{C} / \mathrm{C}$ genotype $(\mathrm{n}=$ 10; median OS, 15.6 months) in USA. Sharp et al. 2008) founded (that For A1298C, compared with AA subjects, CC subjects had modest, non-significant, reduced risk (multivariate OR $=0.81(95 \%$ CI $0.45,1.49$ ) in UK .These results agreement with our result for CC subjects, but disagree for AA subjects.

The present results showed that Comparing all studied cases of colorectal cancer to that of healthy controls regarding their combined genotypes of C677T and A1298C polymorphisms of MTHFR gene, it is noted that cases had a significantly lower frequency of combined (CC and AA) genotypes and (CT and AA) genotypes compared to controls $(6.25 \%$ vs. $18.9 \%, \mathrm{p}=$ $0.03 \& 11 \%$ vs. $25.6 \%, \mathrm{p}=0.02)$.while they had a significantly higher frequency of combined (TT and AC) genotypes (11\% vs. $0 \%, \mathrm{p}=0.001)$. These results were in agreement with our results for the combined genotype 677CT plus 1298AA . El Awady et al. (2009) founded that The combined genotype MTHFR 1298CC + AC frequencies were $86 \%$ with OR 3.71 [95\% CI 1.28-10.78] in carcinoma tissues, 69\% with OR 1.35 [95\%CI $0.57-3.21$ ] in germ line of patients and $62 \%$ in controls. The combined genotype 677CT plus any of the following genotypes 1298AA, AC or CC enhanced risk of Colorectal carcinomas (CRC), when comparing germ line DNA polymorphism of patients versus peripheral blood DNA of control subjects with OR 4.5 [95\%CI $0.94-21.56]$, OR $3.12 \quad$ [95\%CI $0.79-12.36]$ and OR 18 [95\%CI $1.56-$ 207.5], respectively, suggesting strong genetic predisposition of certain Egyptian population to Colorectal carcinomas (CRC) in Egypt . These results are in agreement 
with our results for ( $677 \mathrm{CC}+1298$ AA).Eaton et al.(2005) founded that strong inverse associations between combined MTHFR genotypes and MSI (677 CC+1298 AC/CC, OR, 0.09; 95\% CI, 0.01-0.59; 677 CT/TT+1298 AA, OR, 0.13; 95\% CI, 0.02-0.85) compared with the combined wild-type genotypes (677 CC+1298 AA) in USA .

Regarding normal and abnormal cases of colorectal cancer among tumor marker , hepatic and completely blood count analysis, no higher association between C677T ,A1298C polymorphisms and those founded in the current study.

Possible explanation for these variations in polymorphisms may be due to variations in ethnic background of the cases and controls or due to variation in cases presentations.

Conclusions: Our findings indicate that C677T and A1298C polymorphisms of MTHFR gene were found to be associated with development of colorectal cancer amang Egyptian patients. Mutant TT genotype of C677T, mutant, AC and wild AA genotypes of A1298C, C and A alleles of A1298C may be considered genetic risk factors for development of colorectal cancer. Maximum risk combined genotypes included (CC and AA), (CT and AA) and (TT and AC).

\section{References}

1.Parkin DM, Bray F, Ferlay J, Pisani P, (2005) : Global cancer statistics, 2002. CA Cancer J Clin. ., 55(2):74-108.

2. Stewart SL, Wike JM, Kato I, Lewis DR, Michaud F, (2006): A population- based study of colorectal cancer histology in the United States, Cancer., 107(5 Suppl):1128-41.

3. Donnelly JG, (2001) : Folic acid. Crit Rev Clin Lab Sci.,38(3):183-223.

4. Fowler B, (2005) : Homocysteine: overview of biochemistry, molecular biology, and role in disease processes. Semin Vasc Med .,5(2):7786.

5. Toffoli G, De Mattia E, (2008) : Pharmacogenetic relevance of MTHFR polymorphisms. Pharmacogenomics ., 9(9):1195-206.

6. Friedman G, Goldschmidt N, Friedlander

Y et al, (1999) : A common mutation A1298C in human methylenetetrahydrofolate reductase gene: association with plasma total homocysteine and folate concentrations. J Nutr.,129:1656-61.

7. Almawi WY, Ameen G, Tamim $\mathrm{H}$ et al, (2004) : Factor V G1691A, prothrombin G20210A, and methylenetetrahydrofolate reductase [MTHFR] C677T gene polymorphism in angiographically documented coronary artery disease. J Thromb Thrombolysis., 17(3):199205.

8. Van der Put NM, Gabreels F, Stevens EM et al, (1998): A second common mutation in the methylenetetrahydrofolate reductase gene: An additional risk factor for neural-tube defects? Am J Hum Genet., 62(5):1044-51.

9. Hanson RL, Imperatore G, Narayan KM, Roumain J et al , (2001) : Family and genetic studies of indices of insulin sensitivity and insulin secretion in Pima Indians. Diabetes Metab Res Rev.,17(4):296-303.

10. Friso S, Choi SW, Girelli D et al ,(2002) : A common mutation in the 5,10methylenetetrahydrofolate reductase gene affects genomic DNA methylation through an interaction with folate status. Proc Natl Acad Sci ., 99(8):5606-11.

11. Choi SW, Mason JB, (2002) : Folate status: effects on pathways of colorectal carcinogenesis., J Nutr., 132:2413S-8S

12. Siemianowicz K, Gminski J, Garczorz W, Slabiak $N$ et al ,(2003): Methylenetetrahydrofolate reductase gene C677T and A1298C polymorphisms in patients with small cell and non-small cell lung cancer. Oncol Rep.,10(5):1341-4.

13. Ferlay, J., Bray, F., Pisani, P. \& Parkin, D.M. (2004) : GLOBOCAN 2002: Cancer Incidence, Mortality and Prevalence Worldwide. IARC CancerBase No. 5, version 2.0., Lyon, IARCPress.

14. Sharp L, Little J, (2004) : Polymorphisms in genes involved in folate metabolism and colorectal neoplasia: a HuGE review. Am J Epidemiol; 159: 423-43.

15. Blount BC, Mack MM, Wehr CM, et al , (1997) : Folate deficiency causes uracil misincorporation into human DNA and chromosome breakage: implications for cancer and neuronal damage. Proc Natl Acad Sci USA 1997; 94: 3290-3295.

16. Duthie SJ, (1999) : Folic acid deficiency and cancer: mechanisms of DNA instability. $\mathrm{Br}$ Med Bull; 55: 578-92.

17. Duthie SJ, Narayanan S, Blum S, Piric L, Brand G,(2000) : Folate deficiency in vitro induces uracil misincorporation and DNA hypomethylation and inhibits DNA excision 
repair in immortalized normal colon epithelial cells. Nutr Cancer., 37: 245-51.

18. Toyota M, Ahuja N, Ohe-Toyota $M$ et al, (1999) : $\mathrm{CpG}$ island methylator phenotype in colorectal cancer. Proc Natl Acad Sci USA., 96: 8681-6.

19. Van Rijnsoever M, Grieu F, Elsaleh $\mathbf{H}$ et al, (2002) : Characterisation of colorectal cancers showing hypermethylation at multiple CpG islands. Gut ., 51: 797-802.

20. El Awady MK, Karim AM, Hanna LS et al, (2009) : Methylenetetrahydrofolate reductase gene polymorphisms and the risk of colorectal carcinoma in a sample of Egyptian individuals. Cancer Biomark., 5(6):233-40.

21 . Levine AJ, Figueiredo JC, Lee W, Poynter JN et al , ( 2010 ) : Genetic variability in the MTHFR gene and colorectal cancer risk using the colorectal cancer family registry. Cancer Epidemiol Biomarkers Prev.,19(1):89100.

22. Cui LH, Shin MH, Kweon SS, Kim HN et al , (2010) : Methylenetetrahydrofolate reductase $\mathrm{C677T}$ polymorphism in patients with gastric and colorectal cancer in a Korean population. BMC Cancer. , 26;10(1):236.

23. Le Marchand L, Wilkens LR, Kolonel LN et al, (2005) : The MTHFR C677T polymorphism and colorectal cancer: the multiethnic cohort study. Cancer Epidemiol Biomarkers Prev.,14(5):1198-203.

24. Kono S, Chen K, (2005) : Genetic polymorphisms of methylenetetrahydrofolate reductase and colorectal cancer and adenoma. ancer Sci . ,96(9):535-42.

25. Mokarram P, Naghibalhossaini F, Saberi Firoozi $M$ et al, (2008) :
Methylenetetrahydrofolate reductase C677T genotype affects promoter methylation of tumor-specific genes in sporadic colorectal cancer through an interaction with folate/vitamin B12 status. World J Gastroenterol.,14(23):3662-71.

26. Chandy S, Sadananda Adiga MN, Ramachandra $\mathrm{N}$ et al , (2010) : Association of methylenetetrahydrofolate reductase gene polymorphisms \& colorectal cancer in India. Indian J Med Res.,131:659-64.

27. Curtin K, Bigler J, Slattery ML et al ,(2004) : MTHFR C677T and A1298C polymorphisms: diet, estrogen, and risk of colon cancer. Cancer Epidemiol Biomarkers Prev. ,13(2):285-92.

28. Zhang W, Press OA, Haiman CA et al, (2007): Association of methylenetetrahydrofolate reductase gene polymorphisms and sex-specific survival in patients with metastatic colon cancer. J Clin Oncol., 25(24):3726-31.

29. Sharp L, Little J, Brockton NT et al, (2008) : Polymorphisms in the methylenetetrahydrofolate reductase (MTHFR) gene, intakes of folate and related $\mathrm{B}$ vitamins and colorectal cancer: a case-control study in a population with relatively low folate intake. $\mathrm{Br} \mathrm{J}$ Nutr. , 99(2):379-89. Epub 2007 Dec 6.

30. Eaton AM, Sandler R, Carethers JM et al, (2005) : 5,10-methylenetetrahydrofolate reductase 677 and 1298 polymorphisms, folate intake, and microsatellite instability in colon cancer. Cancer Epidemiol Biomarkers Prev.,14(8):2023-9. 


\title{
التحورات القاعدية في جين الميثلين تتراهيدروفوليت ردكتيز كعوامل خطيره لحدوث سرطان القولون والمستقيم بين المرضين المصرين المينين
}

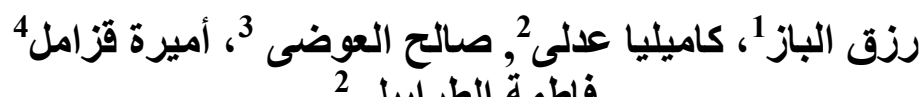 \\ فاطمة الطر ابيلى الع 2 \\ 1 وحدة الور اثةــ مستشفى الأطفال- جامعة المنصورة- مصر

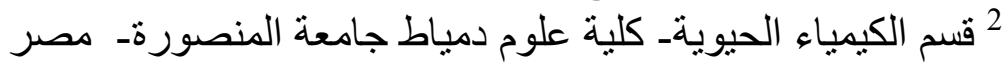

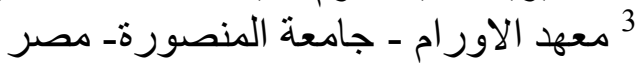

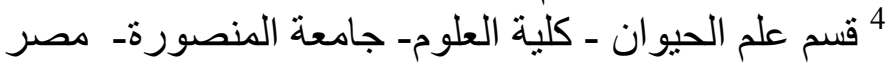

سرطان القولون والمستقيم هو مرض يصيب الخلايا الطبيعية حيث تبدأ بطانة القولون أو المستقيم

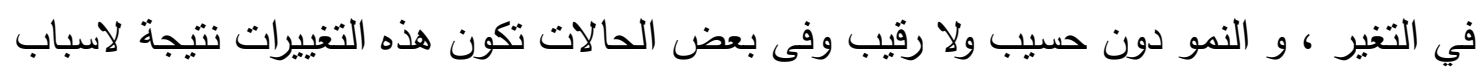
وراثيه. استهدفت هذه الدراسه اثثان من التحورات القاعدية المفرده في جين الميثيلين

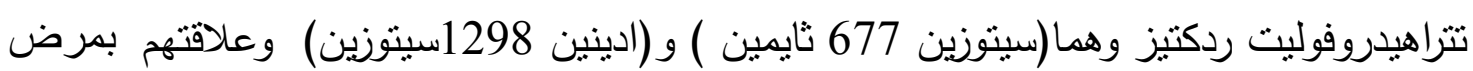
سرطان القولون و المستقيم بين مرضي مصني التينين مصرين.

اوضحت هذه الدر اسه وجود نسبة احصائية معنويه عالية بالتركيب الجيني( ثايمين ثايمين)

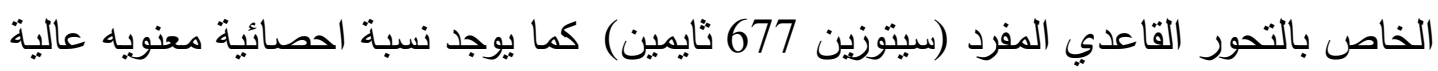

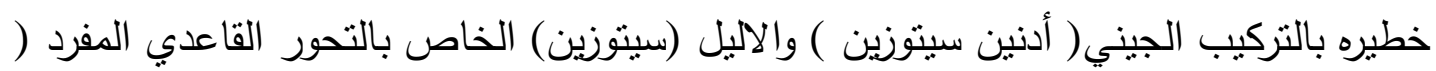

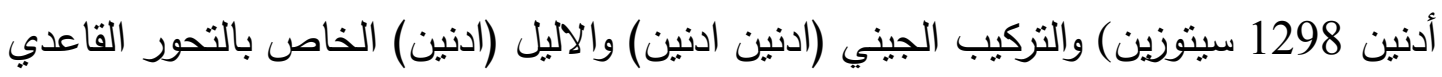

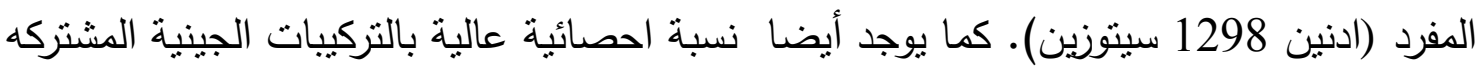

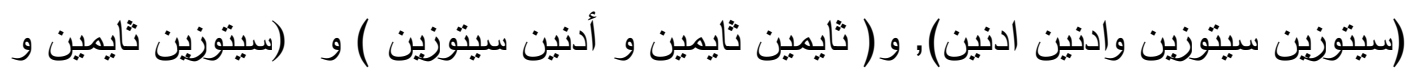
أدنين أدنين) بين حالات مرضي سرطان القولون عنها في الائن الصحاء. 